\title{
ANALYSIS OF ERRORS IN SOLVING GEOMETRY PROBLEMS REVIEWED FROM WRITTEN MATHEMATICAL COMMUNICATION SKILLS OF TEACHER CANDIDATES
}

\author{
Radiusman $^{1 *}$, Maslina Simanjuntak ${ }^{2}$ \\ ${ }^{1}$ Department of Primary School Teacher Education, Universitas Mataram, Indonesia \\ ${ }^{2}$ Department of Mathematics Education, Universitas Negeri Surabaya, Indonesia \\ *Corresponding author: radius_saragih88@unram.ac.id
}

\begin{tabular}{|c|c|}
\hline Article Info & ABSTRACT \\
\hline Article history: & \multirow{8}{*}{$\begin{array}{l}\text { This descriptive qualitative research aims to analyze the mistakes } \\
\text { of primary school teacher candidates in solving geometry problems } \\
\text { reviewed from mathematical written communication skills. This } \\
\text { research was conducted on } 37 \text { students who were in the } 2 \text { nd } \\
\text { semester and took } 3 \text { people as research subjects with the criteria of } \\
\text { moderate written communication skills. Data collection techniques } \\
\text { were carried out using tests and interviews. The written } \\
\text { mathematical communication test was given in the form of a } \\
\text { description where each question contains one written mathematical } \\
\text { communication indicator. The results of this study indicated that } \\
\text { the mistakes were: low knowledge of prerequisite concepts, lack of } \\
\text { student experience in working on problems, weak imagination in } \\
\text { connecting statements, and low ability to perform calculations. }\end{array}$} \\
\hline Received: January 5, 2021 & \\
\hline : February 24, 2021 & \\
\hline Published: March 13, 2021 & \\
\hline Keywords: & \\
\hline Analysis of error & \\
\hline Geometry & \\
\hline Mathematical communication & \\
\hline
\end{tabular}

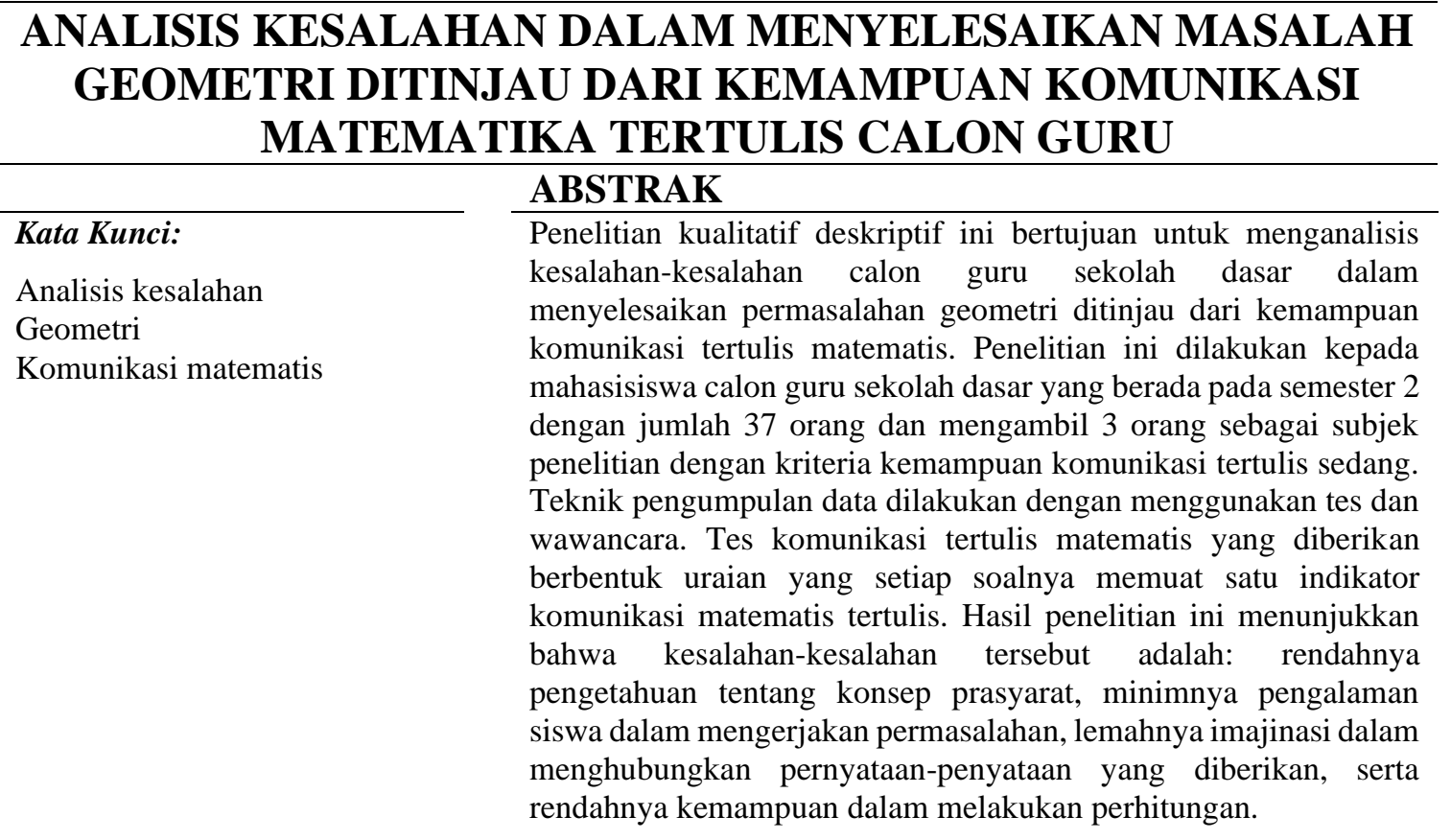

(C) 2021 Unit Riset dan Publikasi Ilmiah FTK UIN Raden Intan Lampung 


\section{INTRODUCTION}

Communication is one of the standard mathematical abilities that students must have and be developed for each student [1]. Practicing communication skills is necessary because mathematical communication is a tool that can be used to share ideas, describe, and explain concepts systematically and clearly. Communication skills play an important role in the development of abilities in terms of understanding concepts, thinking, problemsolving skills, and reasoning in mathematics [2], [3]. Mathematical communication skills are also useful for convincing other people who have different opinions. In addition, mathematical communication can also support students in learning new mathematical concepts that require images, use of objects, verbal explanations using diagrams, writing and using mathematical symbols [1].

Mathematical communication is divided into 2 parts, oral and written communication [4]. Oral communication consists of reading, listening, discussing, explaining, and sharing information, while written communication consists of expressing mathematical ideas through pictures/graphs, tables, algebraic equations, or by writing things down in everyday language. Students can write down everything that is on their minds through written communication. Written communication refers to the change or transmission of ideas from structured knowledge into writing [5]. Besides, written communication is also an ability that shows students have been able to solve mathematical problems procedurally. However, there are still many students who experience errors in solving mathematical problems procedurally because mathematics is still considered too abstract and difficult to understand, especially geometry. [6], [7].

Geometry is a mathematical concept that must be taught at every level of education [1]. Geometry is very important and very relatedly close in everyday life and has links with scientific, technological, and professional subjects [8] and is considered to be one of the topics that have an influence on the progress of the nation [9]. The topic of geometry is also inseparable from measurement and spatial [10]. In geometry, there are several aspects of geometry taught in learning at each level of elementary school grades [11]. This is evidenced by the introduction of geometry in elementary school textbooks in Indonesia. Topics taught include planning a figure, classifying a plane figure, calculating the area of a plane figure, recognizing a solid figure, calculating the surface area and volume of a solid figure. However, there are still many students who have difficulty in learning geometry.

Students' understanding in geometric concepts is lower than students' understanding of other mathematical concepts, such as statistics and measurement [12]. This is indicated by the weak ability of students to absorb geometry in various countries in the world, such as understanding circular geometry in the West African region [13], understand the formation of a cube net in Slovakia [14], relates the measured quantity such as length, circumference, area [11] and spacial abilities in the United States [15], and the application of the concept of surface area and volume in Ecuador and the United States [16]. Many students only reach level 3 (highest level: 5) in solving geometry problems [17]. Furthermore, the lack of application of geometric concepts in everyday life makes students often fail to understand concepts and solve geometric problems [18]. The students' lack of understanding of geometry is also caused by the low ability of students to imagine the geometry [19] Lack of students' imagination also limits students' ability to perform visual perceptions [20], [21].

The next factor that causes students to find it difficult to understand the concept of geometry is the teacher's dominating role in learning activities and the teacher's weak knowledge of concepts [22]. Even teachers still have difficulty in understanding the concept of geometry and the application of geometry in everyday life [23] so that students 
do not have a solid basis for understanding geometry, and students are not able to follow advanced geometry topics [24]. Furthermore, if the teacher carries out conventional learning activities, the teacher only teaches the mathematics curriculum according to the content written in the textbook without using media assistance. This results in students only being passive listeners [25] and limited student activity in imagining the application of geometry in real life.

Errors to the concept of geometry do not only occur in elementary school students. This also happens to prospective elementary school teachers at the University of Mataram, who should be expected to be able to provide the right concept to students after completing studies at the institution. Based on the results of the geometry tests tested on prospective elementary school teachers, there are still many errors in solving geometry problems. The location of the errors made in the process of solving geometric problems are errors in describing planes in accordance with the questions given, errors in understanding the elements of plane geometry, errors in the relationships between angles and their calculations, and calculation of the Pythagorean theorem. Based on the results of this work, this study will analyze the errors of prospective teachers in solving geometry problems.

Analysis of the errors of prospective elementary school teachers in solving geometry problems is important to do to determine the level of understanding of prospective elementary school teachers towards geometry material. Furthermore, this error analysis is also carried out so that prospective teacher students can improve their existing geometric concepts. It is hoped that the understanding of prospective teacher students of the basic concepts of geometry can assist prospective teachers in teaching geometry material after completing education and dealing directly with students at the institution where they work..

Research on analyzing student errors in solving geometry has been done a lot, including: analysis of errors in solving geometry in terms of Newman's Procedure [26], analysis of student errors in solving geometry problems in terms of misconceptions, procedures, and calculations [27], the types of errors that often make in solving geometry problems [28], and student error analysis in solving geometry problems [29]. The previous research was limited to analyzing the location of the error, but not in terms of the mathematical abilities of the research subject. Based on this reason, this study analyzed the errors of prospective elementary school teachers in solving geometry problems in terms of mathematical communication.

In this study, researchers will analyze the errors of prospective elementary school teachers in solving geometry problems in terms of written mathematical communication with the following indicators: expressing mathematical ideas by writing and describing them in visual form, interpreting mathematical ideas presented in written form, and using vocabulary to express ideas, describe relationships and create models [4]. This research is important to do to provide an understanding to prospective elementary school teachers about the importance of mathematical written communication skills on students' understanding and knowledge of the concept of geometry.

\section{METHOD}

This research is a qualitative study using a descriptive approach. This study aims to analyze the mistakes of elementary school teacher candidate students in solving geometry problems in terms of written mathematical communication skills. This research was conducted during the pandemic on second semester students of elementary school education at the University of Mataram. The test was carried out on 37 students and then took 3 people to be research subjects with the criteria for moderate academic ability based on the test results obtained. Taking 3 people as research subjects because these students 
have already represented all the abilities of students that have been tested. Data collection techniques in this study were obtained through tests and interviews. The test is in the form of an essay consisting of 3 questions, where each question contains an indicator of mathematical written communication skills. The indicators of written mathematical communication used in this study are to express mathematical ideas by writing and describing them in visual form, interpreting mathematical ideas presented in written form, and using vocabulary to express ideas, describe relationships and create models. [4]. The data analysis technique was carried out by analyzing the errors of prospective elementary school teachers in solving geometrical problems in terms of mathematical written communication skills. The research process can be seen in Figure 1.

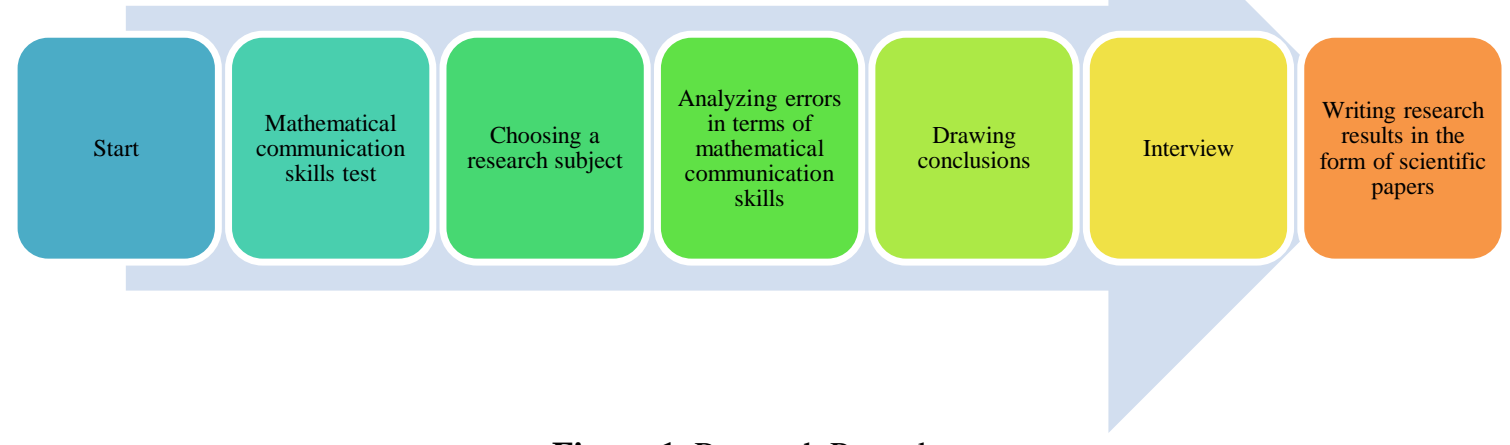

Figure 1. Research Procedure

\section{RESULTS AND DISCUSSION}

Based on the work of prospective teachers in solving geometry problems, the unattainable written mathematical communication indicators can be seen in Table 1 .

Table 1. Unattainable Mathematical Written Communication Indicators

\begin{tabular}{clc}
\hline No & \multicolumn{1}{c}{ Mathematical Written Communication Indicator } & Students Who Answered Wrong \\
\hline 1 & $\begin{array}{l}\text { Expressing mathematical ideas by writing and describing } \\
\text { them in visual form }\end{array}$ & 30 \\
2 & Interpreting mathematical ideas presented in written form & 23 \\
3 & $\begin{array}{l}\text { Using vocabulary to express ideas, describe relationships, } \\
\text { and create models }\end{array}$ & 30 \\
\hline
\end{tabular}

Based on these results, the next step will be to analyze the place of errors of prospective elementary school teachers in solving geometry problems based on indicators of written mathematical communication skills and based on selected research subjects.

\subsection{Expressing Mathematical Ideas by Writing and Describing Them in Visual Form}

\subsubsection{Research Subject 1 (RS1)}

Based on the problems given, there are various types of errors made by this research subject. The work results of RS1 can be seen in Figure 2. 


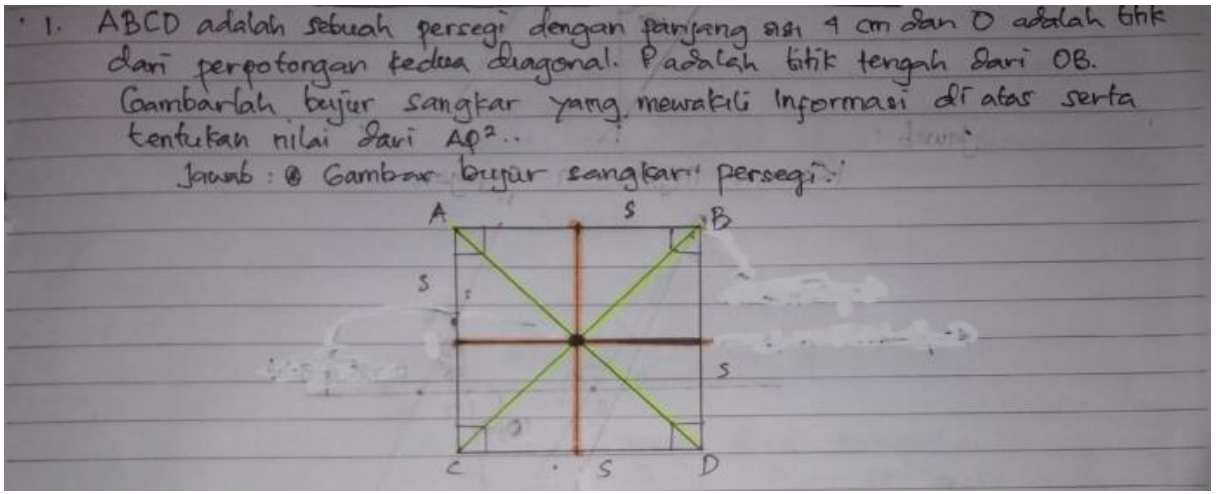

Figure 2. RS1 Work Result on Indicator 1

Based on Figure 2, it can be seen that RS1 made various errors in solving the problems given. The mistakes made in solving the problem are: RS1 is not able to draw a square according to the information provided on the problem. This can be seen from the absence of point $O$ and point $P$ which are the midpoints on line $O B$. In addition, RS1 did not indicate that a rectangle has the same side length or write down the side length according to the problem. Another mistake that RS1 made is not writing the name of the angle square according to the direction of rotation. This will affect the resolution of these problems.

\subsubsection{Research Subject 2 (RS2)}

Based on the problems given, the results of RS2's work in solving indicator problems: expressing mathematical ideas by writing and describing them in visual, can be seen in Figure 3.

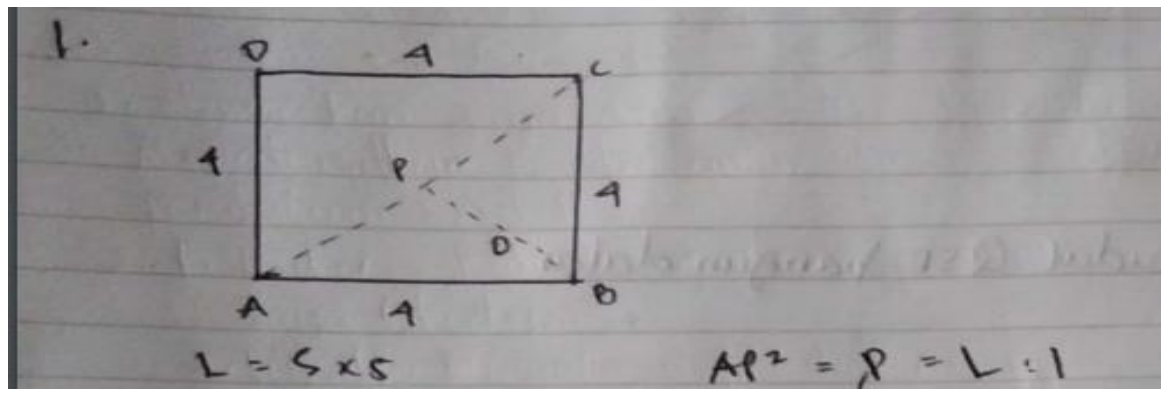

Figure 3. RS2 Work Result on Indicator 1

Based on Figure 3, the error made by RS2 is that RS2 was unable to draw a square according to the information provided. This can be seen from the writing of point $P$ which is the intersection point between the diagonal of the plane and point $O$ to be the point that lies between the intersection of the diagonal of the plane and point $B$. Furthermore, RS2 did not write a symbol stating that point $O$ is the midpoint between the center point and point $B$. Another mistake that RS2 made is not writing the square angle symbol which states that the magnitude of each corner square is $90^{\circ}$.

\subsubsection{Research Subject 3 (RS3)}

The results of RS3 work in solving a geometry problem with indicator: expressing mathematical ideas by writing and describing them in visual form, can be seen in Figure 4. 


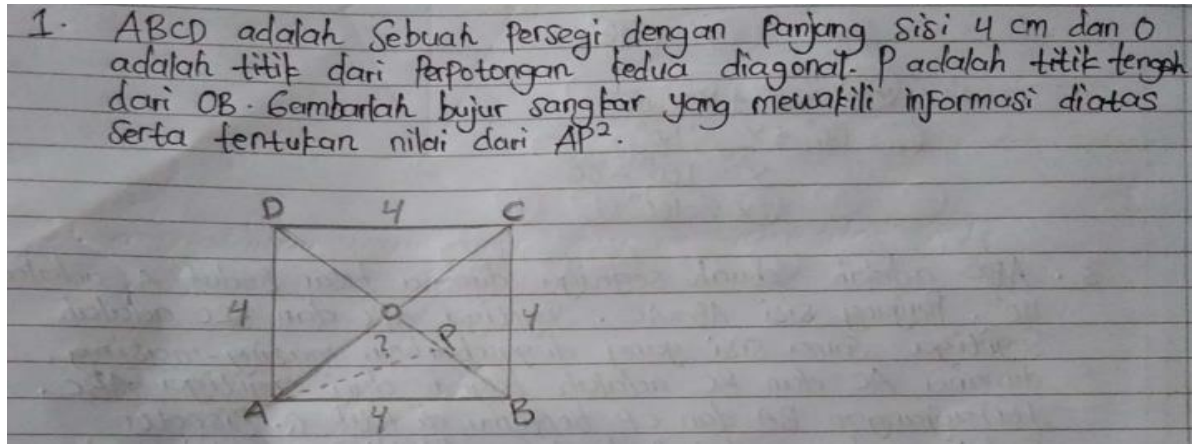

Figure 4. RS3 Work Resuls on Indicator 1

Based on Figure 4, it can be seen that the error that RS3 made was not writing the point that became the intersection between the two diagonals of the plane, namely point $\mathrm{O}$. RS3 also did not write a symbol that point $\mathrm{P}$ was the midpoint between the center point and point $\mathrm{B}$. Another error made by RS3 is not to write down the angles of each angle square.

\subsection{Interpreting Mathematical Ideas Presented in Written}

\subsubsection{Research Subject 1 (RS1)}

Based on the problem, the result of RS1's work in solving a geometry problem with indicator interpreting mathematical ideas presented in written form can be seen in Figure 5 .

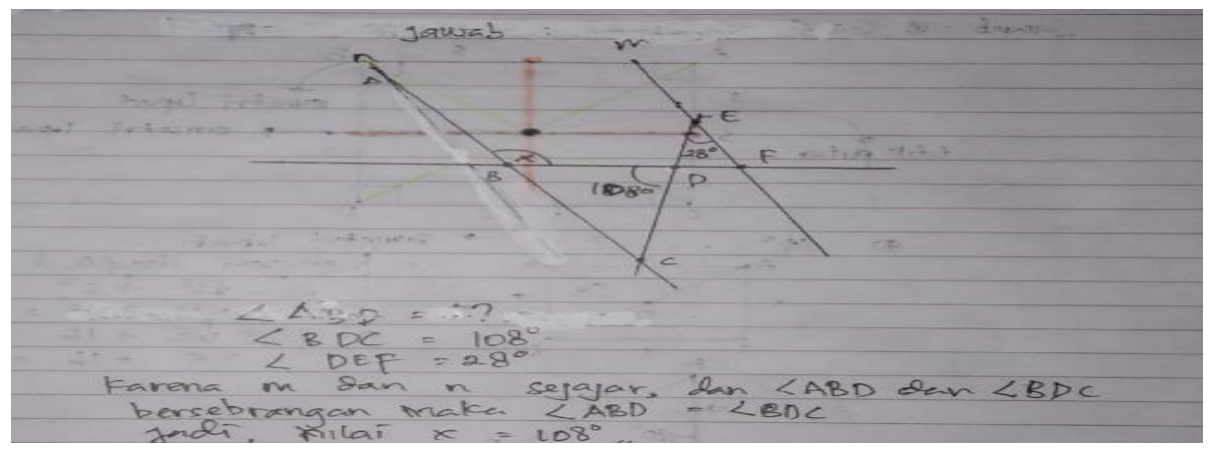

Figure 5. RS1 Work Result on Indicator 2

Based on Figure 5, it can be seen that RS1 is unable to write that the symbol of the two lines is parallel, RS1 also does not know the correct concept of the correlation between the two angles. Based on the result of the answer, it is known that SP1 wrote the wrong correlation and stated that $\angle A B D$ and $\angle B D C$ are opposite each other. To determine the correlation of the angles across, then RS1 should make a new point (for example point $G$ ) which lies on the line $\mathrm{m}$ so that the point $E, F$ and $G$ lies in line $m$. Furthermore, based on the concept of correlation between angles it can be written that $\angle A B D$ and $\angle D F G$ have angles in opposite correlation, so they have the same angles. Furthermore, based on the concept of correlation between angles, calculations can be made to find the value of the angle. 


\subsubsection{Research Subject 2 (RS2)}

The result of RS2's work in solving indicator of interpreting mathematical ideas presented in Figure 6.

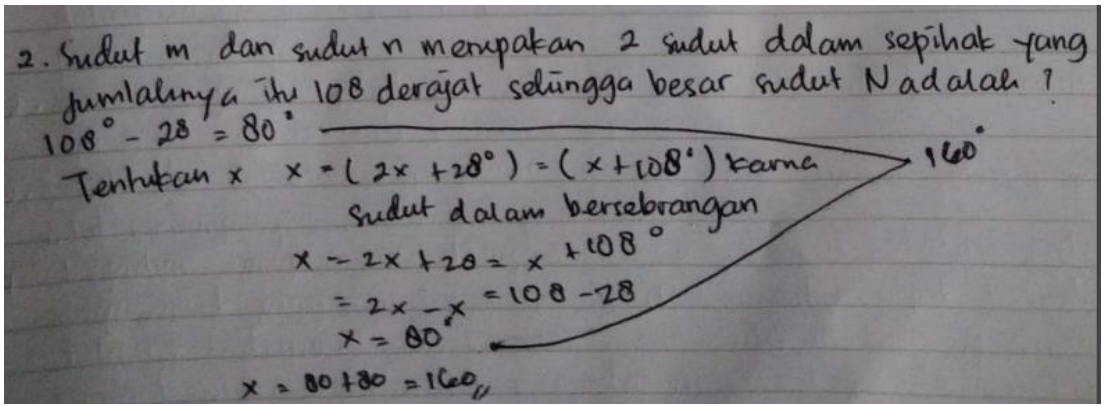

Figure 6. RS2 Work Result on Indicator 2

Based on Figure 6, the error made by RS2 is that RS2 wrote that $m$ and $n$ are unilateral angles. This is no longer consistent with the problem which stated that $m$ and $n$ are a line. SP2 also wrote the operations $x=\left(2 x+28^{0}\right)=\left(x+108^{0}\right)$ is the inner angle opposite. Based on the problem, it cannot be known the reason for the operation. Based on the results of calculations carried out by RS2, it can also be seen that RS2 is not able to perform the right operation to determine the value $x$.

\subsubsection{Research Subject 3 (RS3)}

The result of RS3's work in solving a geometry problem with indicator interpreting mathematical ideas presented in written form can be seen in Figure 7 ..

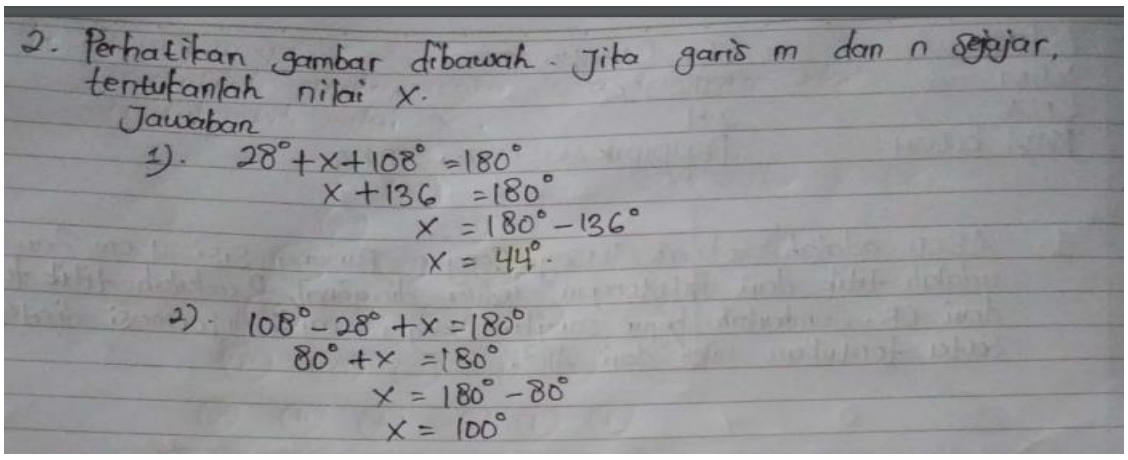

Figure 7. RS3 Work Result on Indicator 2

Based on Figure 7, it can be seen that RS3 is unable to determine the correlation between angles according to the given problem. RS3 also made an error in performing angle operations to determine the result that corresponds to the given problem. This makes RS3 find that there are different values for $x$ whereas according to the problem, the $x$ values obtained should be the same (single).

\subsection{Describing Relationships and Creating Models}

\subsubsection{Research Subject 1 (RS1)}

The result of RS1's work in solving a problem with indicator describing relationships and making models can be seen in Figure 8. 


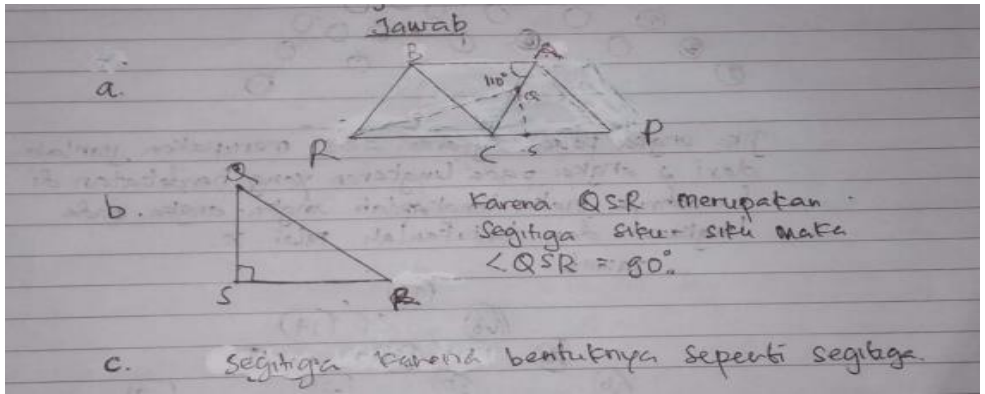

Figure 8. RS1 Work Result on Indicator 3

Based on Figure 8, it can be seen that RS1 is not able to make a relationship between the statements given and the requested shape. Based on the question, the plane of the SRQC, RS1 has proven that the plane in question is a rectangle. Furthermore, with the further informations given, a trapezoidal plane will be formed.

\subsubsection{Research Subject 2 (RS2)}

The result of RS2's work in solving a geometry problem with indicator describing relationships and making models can be seen in Figure 9.

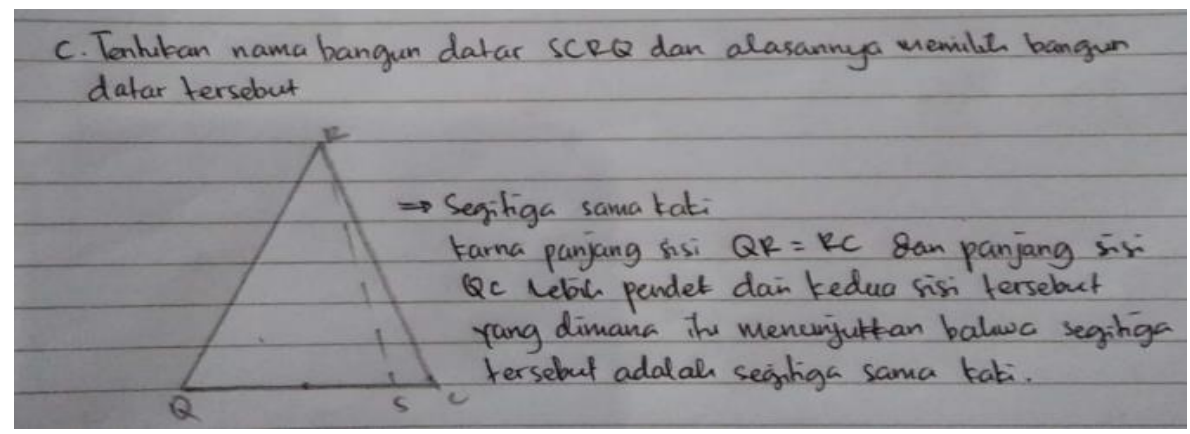

Figure 9. RS2 Work Result on Indicator 3

Based on Figure 9, it can be seen that RS2 is unable to relate the statement to the requested geometric shape, so RS2 answers the triangle.

\subsubsection{Research Subject 3 (RS3)}

The result of RS3's work in solving a geometry problem with indicator describing relationships and making models can be seen in Figure 10.

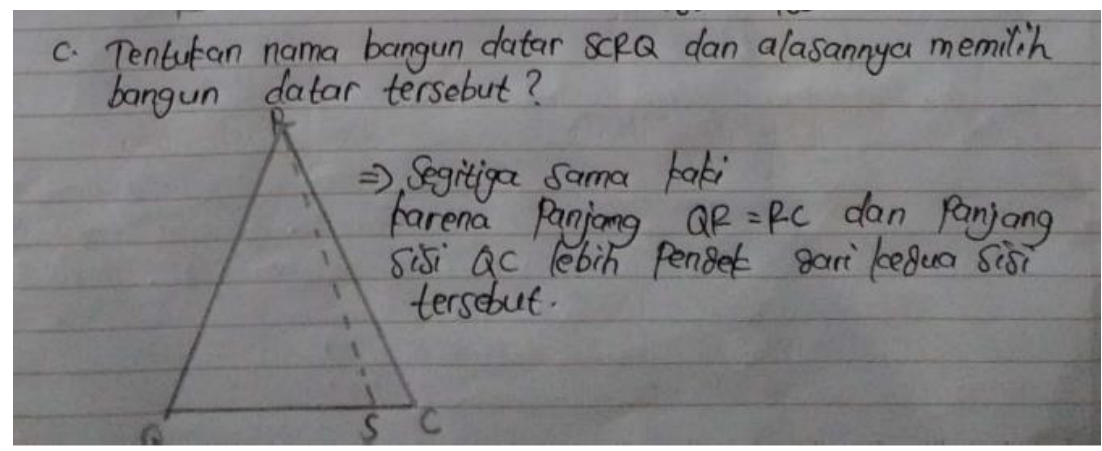

Figure 10. RS3 Work Result on Indicator 3 
Based on Figure 10, it can be seen that RS3 is not able to connect the statements in the problem. This results in RS3 being unable to determine the shape according to the information given.

Based on the results of the analysis previously described, it can be seen that there are still many mistakes made by students (as prospective teachers) in solving geometry problems in terms of mathematical written communication skills. As a result, the research subject made mistakes in solving geometric problems in terms of mathematical communication skills, such as 1) inability to express mathematical ideas by writing and describing them in visual form, 2) inability to interpret mathematical ideas presented in written form, and 3) inability to describe relationships and create models.

In the first indicator, expressing mathematical ideas by writing and describing them in visual form, there are still many mistakes made by respondents, such as not being able to describe the plane according to the statement given in the problem, unable to draw a symbol stating that each side has the same length, and the lack of knowledge of the symbols used in a plane, such as the center point and right angle symbols. The second indicator is interpreting mathematical ideas in writing. The mistakes made are errors in writing the correlation between angles, errors in writing the names of parallel lines, and errors in writing calculation operations that cause the results to be wrong..

Furthermore, the third indicator describes the relationship and makes a model. In this indicator, the mistakes made are that the research subject is unable to make a plane model according to the statements in the problem and write the plane shape according to the properties obtained in accordance with the plane that has been described on the answer sheet. Based on the results of the interviews, information was obtained that the mistakes made by the research subjects were generally caused by several factors: the lack of understanding of the concept of geometrical material, rarely working on geometry problems, and confusion in solving geometric problems [30]. The results also revealed that there were still many mistakes made by students (as prospective teachers) in solving algebraic problems. Apart from misconceptions, symbols, and procedures, there are also other errors such as visual errors, where students cannot determine the name of a shape based on the properties of the shape..

\section{CONCLUSION}

The mistakes made by research subjects in solving geometric problems in terms of written communication skills are basic errors, such as errors in drawing planes, errors in writing plane symbols, and calculation errors in solving problems. Based on the results and discussion, it can be concluded that the error is caused by several factors, including: low knowledge of prior concepts, lack of experience in working on problems, weak imagination in connecting statements and information, and low ability to perform calculations. Based on the results of this study, the researcher can provide suggestions that the teacher must be precise in providing the prerequisite concepts before providing the core material. Furthermore, the teacher must be diligent in giving practice questions to students and supervising students in solving the problems.

\section{REFERENCES}

[1] NCTM, Principles Standards and for School Mathematics. reston: VA: National Council of Teachers of Mathematics, 2000.

[2] R. Charlesworth, "Prekindergarten mathematics: Connecting with national standards," Early Child. Educ. J., vol. 32, no. 4, pp. 229-236, 2005.

[3] H. Y. Jung and S. Reifel, "Promoting children's communication: A kindergarten

Indonesian Journal of Science and Mathematics Education (IJSME) 9 
teacher's conception and practice of effective mathematics instruction," J. Res. Child. Educ., vol. 25, no. 2, pp. 194-210, 2011.

[4] B. I. Ansari, Komunikasi Matematik, Strategi Berpikir dan Manajemen Belajar: Konsep dan Aplikasi. Banda Aceh: PeNA, 2016.

[5] M. K. Gfeller, "A Teacher's Conception of Communication in Geometry Proofs," Sch. Sci. Math., vol. 110, no. 7, pp. 341-351, 2010.

[6] K. K. Bhagat and C. Y. Chang, "Incorporating GeoGebra into geometry learning-A lesson from India," Eurasia J. Math. Sci. Technol. Educ., vol. 11, no. 1, pp. 77-86, 2015.

[7] Z. M. M. Jojo, "The Use of Indigenous Materials in the Teaching and Learning of Geometry," J. Commun., vol. 6, no. 1, pp. 48-56, 2015.

[8] S. Olkun, "Geometric explorations with dynamic geometry applications based on van Hiele levels," Int. J. Math. Teach. Learn., no. January, 2005.

[9] T. Al-ebous, "Effect of the Van Hiele Model in Geometric Concepts Acquisition: The Attitudes towards Geometry and Learning Transfer Effect of the First Three Grades Students in Jordan," Int. Educ. Stud., vol. 9, no. 4, p. 87, 2016.

[10] L. M. Weckbacher and Y. Okamoto, "Mental rotation ability in relation to selfperceptions of high school geometry," Learn. Individ. Differ., vol. 30, pp. 58-63, 2014.

[11] M. D. Steele, "Exploring the mathematical knowledge for teaching geometry and measurement through the design and use of rich assessment tasks," J. Math. Teach. Educ., vol. 16, no. 4, pp. 245-268, 2013.

[12] P. P. Sari, Budiyono, and I. Slamet, "Cooperative learning model with high order thinking skills questions: An understanding on geometry," J. Phys. Conf. Ser., vol. 1013, no. 1, 2018.

[13] S. . Adeniji, S. . Ameen, B. . Dambatta, and R. Orilonise, "Effect of Mastery Learning Approach on Senior Secondary School Students 'Achievement in Geometry," Int. J. Instr., vol. 11, no. 4, pp. 951-952, 2018.

[14] G. Pavlovičová and V. Švecová, "The Development of Spatial Skills through Discovering in the Geometrical Education at Primary School," Procedia-Social Behav. Sci., vol. 186, pp. 990-997, 2015.

[15] J. Moss, Z. Hawes, S. Naqvi, and B. Caswell, “Adapting Japanese Lesson Study to enhance the teaching and learning of geometry and spatial reasoning in early years classrooms: a case study," ZDM Math. Educ., vol. 47, no. 3, pp. 377-390, 2015.

[16] S. . Gillmor and S. . Rabinowich, "Understanding Geometry and Measurment through Service-Learning," Math. Teach. Middle Sch., vol. 19, no. 1, pp. 55-61, 2013.

[17] E. Sudihartinih and E. Mulyana, "Perkuliahan Geometri Transformasi dengan Pendekatan Kontruktivisme untuk Meningkatkan Level Berpikir Geometri van Hiele," J. Pendidik. Mat. Sigma Didat., vol. 3, no. 1, pp. 12-16, 2014.

[18] W. Y. Hwang, A. Hoang, and Y. H. Tu, "Exploring Authentic Contexts with Ubiquitous Geometry to Facilitate Elementary School Students' Geometry Learning," Asia-Pacific Educ. Res., vol. 29, no. 3, pp. 269-283, 2020.

[19] I. Elia, M. van den Heuvel-Panhuizen, and A. Gagatsis, "Geometry Learning in the Early Years: Developing Understanding of Shapes and Space with a Focus on Visualization," in Forging Connections in Early Mathematics Teaching and Learning, V. Kinnear, M. Y. Lai, and T. Muir, Eds. New York: Springer, 2018, pp. 73-59.

[20] D. Zhang, Q. Wang, Y. Ding, and J. J. Liu, "Testing Accommodation or 
Modification?: The Effects of Integrated Object Representation on Enhancing Geometry Performance in Children With and Without Geometry Difficulties," J. Learn. Disabil., vol. 47, no. 6, pp. 569-583, 2014.

[21] H. Gal and L. Linchevski, "To see or not to see: Analyzing difficulties in geometry from the perspective of visual perception," Educ. Stud. Math., vol. 74, no. 2, pp. 163-183, 2010.

[22] A. Kuzniak and J. C. Rauscher, "How do teachers' approaches to geometric work relate to geometry students' learning difficulties?," Educ. Stud. Math., vol. 77, no. 1, pp. 129-147, 2011.

[23] N. M. Seago, J. K. Jacobs, D. J. Heck, C. L. Nelson, and K. A. Malzahn, "Impacting teachers' understanding of geometric similarity: Results from field testing of the learning and teaching geometry professional development materials," Prof. Dev. Educ., vol. 40, no. 4, pp. 627-653, 2014.

[24] D. C. Cox, "Similarity in Middle School Mathematics: At the Crossroads of Geometry and Number," Math. Think. Learn., vol. 15, no. 1, pp. 3-23, 2013.

[25] K. Vidermanova and D. Vallo, "Practical Geometry Tasks as a Method for Teaching Active Learning in Geometry," Procedia - Soc. Behav. Sci., vol. 191, pp. 17961800, 2015.

[26] F. R. Hadiyanto, "Analisis Kesalahan Siswa Kelas VII Dalam Menyelesaikan Soal Cerita Pada Materi Geometri Dengan Menggunakan Newman's Procedure," J. Kaji. Pembelajaran Mat., vol. 3, no. 2, pp. 67-77, 2019.

[27] D. N. Utami, B. Kusmanto, and S. A. Widodo, "Analisis Kesalahan dalam Mengerjakan Soal Geometri," J. Edukasi Mat. dan Sains, vol. 7, no. 1, p. 37, 2019.

[28] T. Solfitri and Y. Roza, "Analisis Kesalahan dalam Menyelesaikan Soal-Soal Geometri Siswa Kelas IX SMPN Se-Kecamatan Tampan Pekanbaru (The Analysis of Error on Solving Geometry Problem of Student at Class IX Junior High School on Tampan Subdistrict Pekanbaru)," Pros. Semirata 2015 Bid. MIPA BKS-PTN Barat, pp. 295-303, 2015.

[29] S. A. Murwati, D. F. Hanianto, and N. D. A. Prasetyo, "Analisis Kesalahan Siswa dalam Mengerjakan Soal Cerita di Topik Geometri dan Faktor-Faktor Penyebabnya," Prism. Pros. Semin. Nas. Mat., vol. 3, no. 1, pp. 358-369, 2020.

[30] A. H. Abdullah, N. L. Z. Abidin, and M. Ali, "Analysis of students' errors in solving Higher Order Thinking Skills (HOTS) problems for the topic of fraction," Asian Soc. Sci., vol. 11, no. 21, pp. 133-142, 2015. 